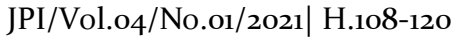

\section{Ragam Storyboard Untuk Produksi Media Pembelajaran}

\author{
Kunto Imbar, ${ }^{\circledR}$ Diana Ariani $^{2}$, Retno Widyaningrum ${ }^{3}$, Regita Syahyani ${ }^{4}$
}

${ }^{1}$ Universitas Negeri Jakarta, DKI Jakarta, Indonesia.

${ }^{2}$ Universitas Negeri Jakarta, DKI Jakarta, Indonesia.

3Universitas Negeri Jakarta, DKI Jakarta, Indonesia.

${ }^{4}$ Universitas Negeri Jakarta, DKI Jakarta, Indonesia.

\section{DOI: https://doi.org/10.21009/IPI.041.14}

\begin{tabular}{l}
\hline Article History \\
\hline Submitted : 2020 \\
Accepted : 2020 \\
Published : 2021 \\
\hline Keywords \\
\hline media linear; media \\
non-linear; \\
pengembangan media; \\
storyboard \\
\hline
\end{tabular}

\begin{abstract}
Abstrak
Mahasiswa sebagai media developer harus mampu mendesain pesan kemudian secara simultan melakukan visualisasi ide dari pesan tersebut sebelum melanjutkannya pada tahap produksi selanjutnya dari beragam format media yang mungkin dikembangkan untuk pembelajaran. Adapun melihat kebutuhan dari para mahasiswa terkait produksi media-media pembelajaran, maka dengan ini peneliti menentukan tujuan dari penelitian ini adalah menghasilkan ragam storyboard untuk produksi media pembelajaran. Model pengembangan yang digunakan pada penelitian pengembangan ini adalah dengan menggunakan framework ADDIE, adapun pada ADDIE ini dilakukan secara linear atau akan terjadi proses kerja yang dilakukan secara kontinyu prosesnya. Berikut langkah-langkah yang akan dilakukan dalam penelitian ini: Analisis (Analyze.), Desain (Design), Pengembangan (Development), Implementasi (Implementation), Evaluasi (Evaluation). Hasil dari penelitian pengembangan ini adalah produk berupa storyboard untuk produksi media digital berdasarkan alur penyajian yang terdiri dari dua format template storyboard linear dan non-linear.
\end{abstract}

\begin{abstract}
The media producer must be able to design the message and then simultaneously visualize the idea of the message before continuing it at the next production stage of various media formats that may be developed for learning. As for seeing the needs of the Education Technology study program students related to the production of learning media, the researcher determined the purpose of this study was to produce a variety of storyboards for the production of instructional media. The ADDIE development framework is used in this development research, while the procedures in this model are carried out linearly or a work process will occur continuously. The following are the steps that will be carried out in this research: Analysis (Analyze.), Design (Design), Development (Implementation), Implementation (Implementation), Evaluation (Evaluation). The output in the form of a storyboard for digital media production is the result of this development, which consists of two storyboard template formats based on linear and non-linear presentation flows.
\end{abstract}

\footnotetext{
Corresponding author

Alamat : Jl. Rawamangun Muka, Gd. Daksinapati lt.2, Teknologi

Pendidikan, Fakultas Ilmu Pendidikan, Universitas Negeri Jakarta,

Jakarta, 13220

E-mail : kuntoimbar@unj.ac.id
} 


\section{PENDAHULUAN}

Berdasarkan analisis kebutuhan dan dengan merujuk pada definisi Association for Educational Communications and Technology (AECT, 2004) Prodi Teknologi Pendidikan FIP UNJ melakukan perubahan konsentrasi pada kurikulumnya. Hal ini disebabkan kompetensi dari Pengembangan Media saat ini sudah menjadi kompetensi yang wajib dimiliki oleh seluruh mahasiswa. Salah satu kualifikasi yang harus dimiliki oleh Teknolog Pendidikan yaitu mampu mengembangkan media dan/atau sumber belajar, dari yang bersifat konvensional hingga pemanfaatan TIK bagi suatu lembaga Pendidikan/diklat secara mandiri. Para lulusan membutuhkan keterampilan dalam menghasilkan media pembelajaran, dimanapun mereka akan berkerja terutama di era digital saat ini.

Pada era digital materi pembelajaran tersaji pada layar-layar alat canggih yang didukung oleh beragam media pembelajaran. Salah satu tahap prosedur yang dilakukan oleh pengembang media pembelajaran yakni menggunakan storyboard. Namun kemampuan dan pemahaman mahasiswa akan storyboard

Tabel 1. Profil Lulusan Program Studi Teknologi Pendidikan FIP UNJ

PROFIL LULUSAN

Teknolog Pembelajaran

Teknolog Kinerja cenderung kurang baik. Salah satu kendala yang dihadapi yakni belum ada format storyboard baku untuk digunakan dalam produksi media. Sehingga, ragam storyboard untuk produksi media ini penting untuk dikembangkan bagi mahasiswa program studi Teknologi Pendidikan FIP UNJ.

Kandriasari dkk, (2019) dalam penelitiannya yang berjudul "How To Develop A Bread Processing Video Storyboard" melakukan penelitian yang berfokus pada pengembangan pedoman video storyboard di praktik pengolahan Roti Taiwan. Adapun hasil penelitian pengembangan storyboard video pedoman adalah langkah awal dalam produksi praktikum pemrosesan kue. Ini bertujuan untuk mendapatkan storyboard video panduan berkualitas di praktikum Roti Taiwan yang sesuai dengan kebutuhan mahasiswa. Hal ini membuktikan bahwa sebuah storyboard sangat menentukan dalam proses produksi media pembelajaran.

Terkait kebutuhan para mahasiswa Program Studi TP FIP UNJ teridentifikasi dibutuhkannya format storyboard yang baku. Atas dasar kebutuhan inilah perlu dikembangkan

\section{DESKRIPSI PROFIL LULUSAN}

a. Mampu melakukan rekayasa belajar dengan cara mendesain, mengembangkan, mengelola, memanfaatkan dan mengevaluasi proses dan sumber belajar dengan menjunjung tinggi etika profesi.

b. Mengembangkan pembelajaran, sumber belajar dan media pembelajaran.

c. Mengembangkan kurikulum mikro (mata pelajaran) di berbagai satuan pendidikan (sekolah dan non-sekolah).

d. Mengembangkan media dan/atau sumber belajar, dari yang bersifat konvensional hingga pemanfaatan TIK bagi suatu lembaga pendidikan secara mandiri.

e. Mengelola sumber belajar serta pemanfaatan TIK untuk pembelajaran.

a. Mampu melakukan rekayasa belajar dengan cara mendesain, mengembangkan, mengelola, memanfaatkan dan mengevaluasi proses dan kinerja organisasi dengan menjunjung tinggi etika profesi.

b. Mengembangkan pelatihan, sumber belajar dan media.

c. Mengembangkan kurikulum mikro (mata pelatihan) di berbagai lembaga diklat

d. Mengembangkan media dan/atau sumber belajar, dari yang bersifat konvensional hingga pemanfaatan TIK bagi suatu lembaga diklat secara mandiri.

e. Mengelola sumber belajar serta pemanfaatan TIK untuk pelatihan.

${ }^{1}$ Kandriasari, A., Situmorang, R., Muslim, S., \& Lagun Siang, J. (2019). HOW TO DEVELOP A BREAD PROCESSING VIDEO STORYBOARD. Asia
Proceedings of Social Sciences, 5(2), 137-141. https://doi.org/10.3158o/apss.v5i2.1132 
ragam storyboard untuk produksi media. Adapun kebutuhan. Untuk memperoleh analisis yang melihat kebutuhan dari para mahasiswa terkait tepat, maka analisis dilakukan oleh para produksi media-media pembelajaran, maka pengembangan media dan disainer pembelajaran dengan ini peneliti menentukan tujuan dari yang sangat lumrah dalam menggunakan penelitian ini adalah menghasilkan ragam storyboard dalam pekerjaannya. Dilanjutkan storyboard untuk produksi media pembelajaran. dengan Disain (Design) Tahap ini dikenal dengan para mahasiswa sebagai media developer harus rancang bangun diatas kertas terlebih dahulu. mampu mendesain pesan kemudian secara Berbagai pertimbangan pada tahap analisis simultan melakukan visualisasi ide dari pesan dimaknai sehingga sebuah rekayasa terhadap tersebut sebelum melanjutkannya pada tahap format storyboard terwujud dengan produksi selanjutnya dari beragam format media pertimbangan atas karakteristiknya. Tahap disain yang mungkin dikembangkan untuk dilakukan dengan mempertimbangkan hasil dari pembelajaran. tahap analisis, sehingga desain yang dihasilkan akan sesuai dengan kebutuhan yang ada.

\section{METODE}

Penelitian ini merujuk pada model pengembangan ADDIE, ADDIE (Analisis, Desain, Pengembangan, Implementasi, dan Evaluasi) adalah model pengembangan dari Desain Sistem Instruksional. ADDIE telah berkembang beberapa kali selama bertahun-tahun menjadi iteratif, dinamis, dan ramah bagi pengguna (pengembang).

Tahap pertama adalah Analisis (Analyze.) Tahap analisis merupakan suatu proses needs assessment (analisis kebutuhan), mengidentifikasi masalah (kebutuhan) dan melakukan analisis tugas (task analyze). Out put yang dihasilkan berupa identifikasi kebutuhan dan analisis tugas yang rinci didasarkan

Tahap

Pengembangan

proses mewujudkan blue-print menjadi kenyataan. Artiny esuatu yang dibutuhkan atau yang terkait dikembangkan pada bentuk yang lebih konkrit. Seiring itu tahap Implementasi (Implementation) dilakukan. Implementasi adalah langkah nyata untuk menerapkan produk yang sedang kita buat. Artinya, pada tahap ini semua yang telah dikembangkan diinstal atau diset sedemikian rupa sesuai dengan peran atau fungsinya agar dapat digunakan. Implementasi dilakukan di tempat / lapangan pekerjaan yang familiar menggunakan storyboard, hal ini bertujuan memastikan produk storyboard yang dihasilkan, sesuai dengan keperluan lapangan pekerjaan.

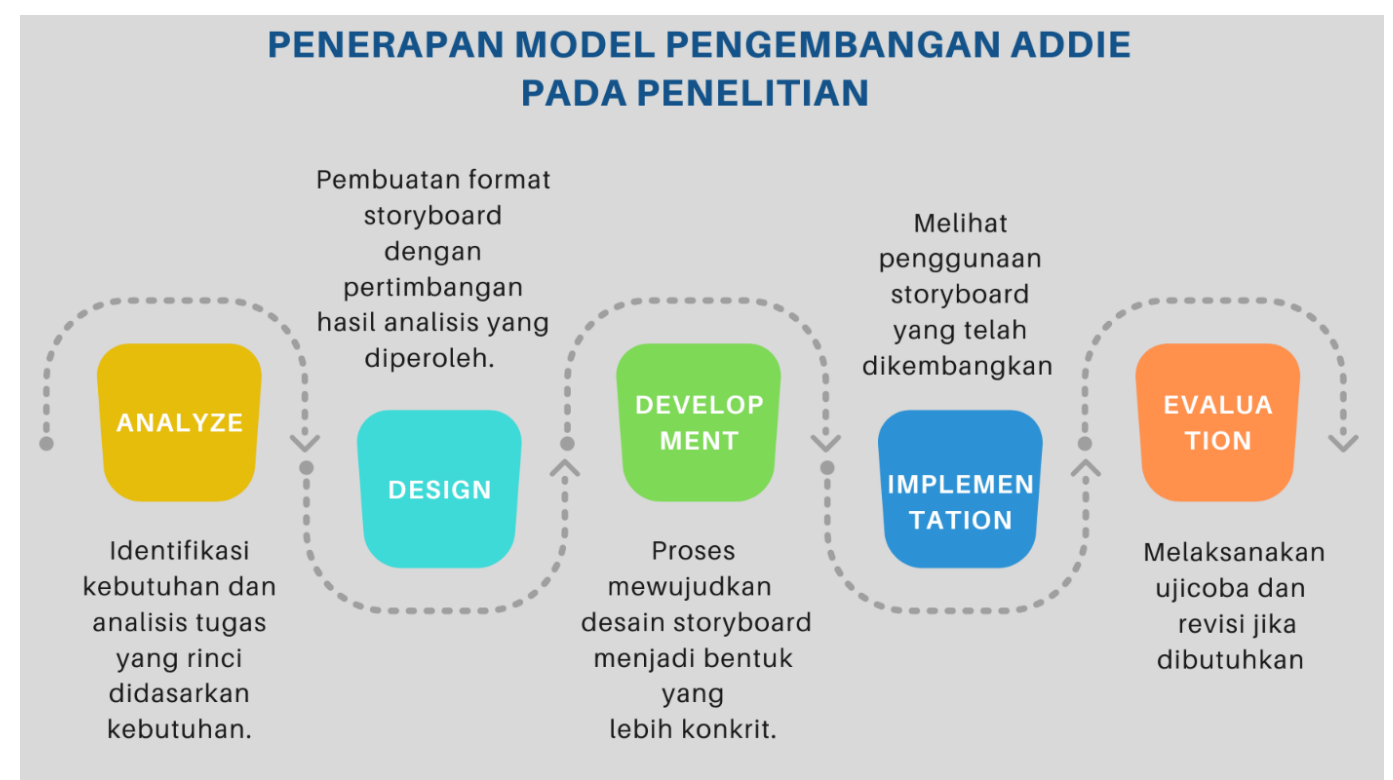

Gambar 1. Model Pengembangan ADDIE 
Namun, seperti sasaran pengembangan yang telah ditentukan, maka mahasiswa Teknologi Pendidikan FIP UNJ juga menjadi sasaran implementasi dari pengembangan ini. Implementasi dilakukan kepada mahasiswa semester akhir yang sedang menyelesaikan skripsi pengembangan media.

Tahap terakhir adalah Evaluasi (Evaluation). Evaluasi adalah proses untuk melihat apakah produk yang sedang dibangun berhasil, sesuai dengan harapan awal atau tidak. Tahap evaluasi bisa dilakukan pada setiap empat tahap diatas yang disebut evaluasi formatif, karena tujuannya untuk kebutuhan perbaikan. Misalnya pada tahap rancangan kita memerlukan review ahli untuk memberikan input terhadap rancangan yang sedang dibuat.

\section{HASIL DAN PEMBAHASAN}

Definisi storyboard menurut Oxford Cambridge and RSA adalah rangkaian diagram yang menunjukkan urutan tampilan. Animator Walt Disney Webb Smith pertama kali menggunakan storyboard pada awal tahun 1930. Smith menggunakan gambar terpisah pada papan buletin untuk menceritakan adegan interaktif, termasuk interativitas website. Biasanya storyboard dapat dibuat seperti cerita bergambar atau komik sederhana. Storyboard merupakan visualisasi ide dari aplikasi yang akan dibangun, sehingga dapat memberikan gambaran dari aplikasi yang akan dihasilkan. Storyboard dapat dikatakan juga visual script yang akan dijadikan outline dari sebuah proyek, ditampilkan shot by shot yang biasa disebut dengan istilah scene. Storyboard sekarang lebih banyak digunakan untuk membuat kerangka pembuatan websites dan proyek media interaktif lainnya seperti iklan, film pendek,games, media pembelajaran interaktif ketika dalam tahap perancangan/desain. Salah satu keuntungan menggunakan.

Ada dua bagian utama storyboard. Yang pertama adalah urutan adegan berbeda untuk menceritakan sebuah cerita. Yang kedua adalah informasi yang disediakan untuk setiap adegan. Storyboard dapat membuat pengguna untuk mengalami perubahan dalam alur cerita untuk memicu reaksi atau ketertarikan yang lebih dalam. Kilas balik, secara cepat menjadi hasil dari pengaturan Storyboard secara kronologis untuk membangun rasa penasaran dan ketertarikan.

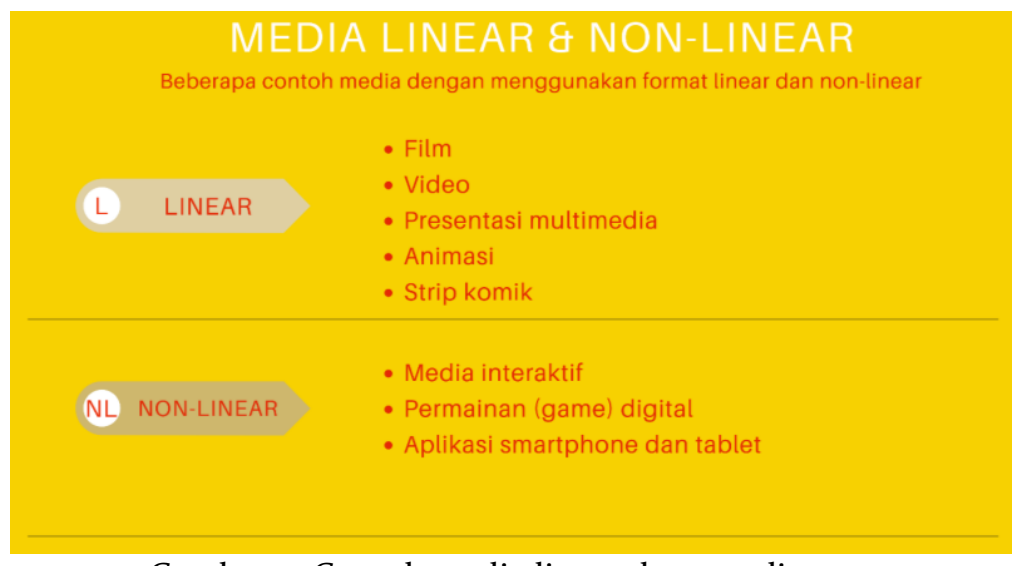

Gambar 2. Contoh media linear dan non-linear.

Disney "The Three Little Pigs". Salah satu film aksi langsung pertama yang menggunakan storyboard sepenuhnya adalah "Gone with the Wind". Melihat peran storyboard dalam proses produksi film, akhirnya storyboard banyak diadaptasi untuk memproduksi media lainnya, termasuk dalam bidang pendidikan.

Storyboard adalah penyusun grafik seperti sekumpulan ilustrasi atau gambar yang ditampilkan secara berurutan untuk tujuan visualisasi grafik bergerak atau urutan media
Seorang pembuat Storyboard harus mampu menceritakan sebuah cerita yang bagus. Untuk mencapainya, mereka harus mengetahui berbagai film, dengan pengertian tampilan yang bagus, komposisi, gambaran berurut dan editing. Mereka harus mampu untuk bekerja secara sendiri atau dalam sebuah bagian tim. Mereka harus mampu menerima arahan dan juga bersiap membuat perubahan terhadap hasil kerja mereka. Untuk proyek tertentu, pembuat Storyboard memerlukan ketrampilan menggambar yang bagus dan kemampuan 


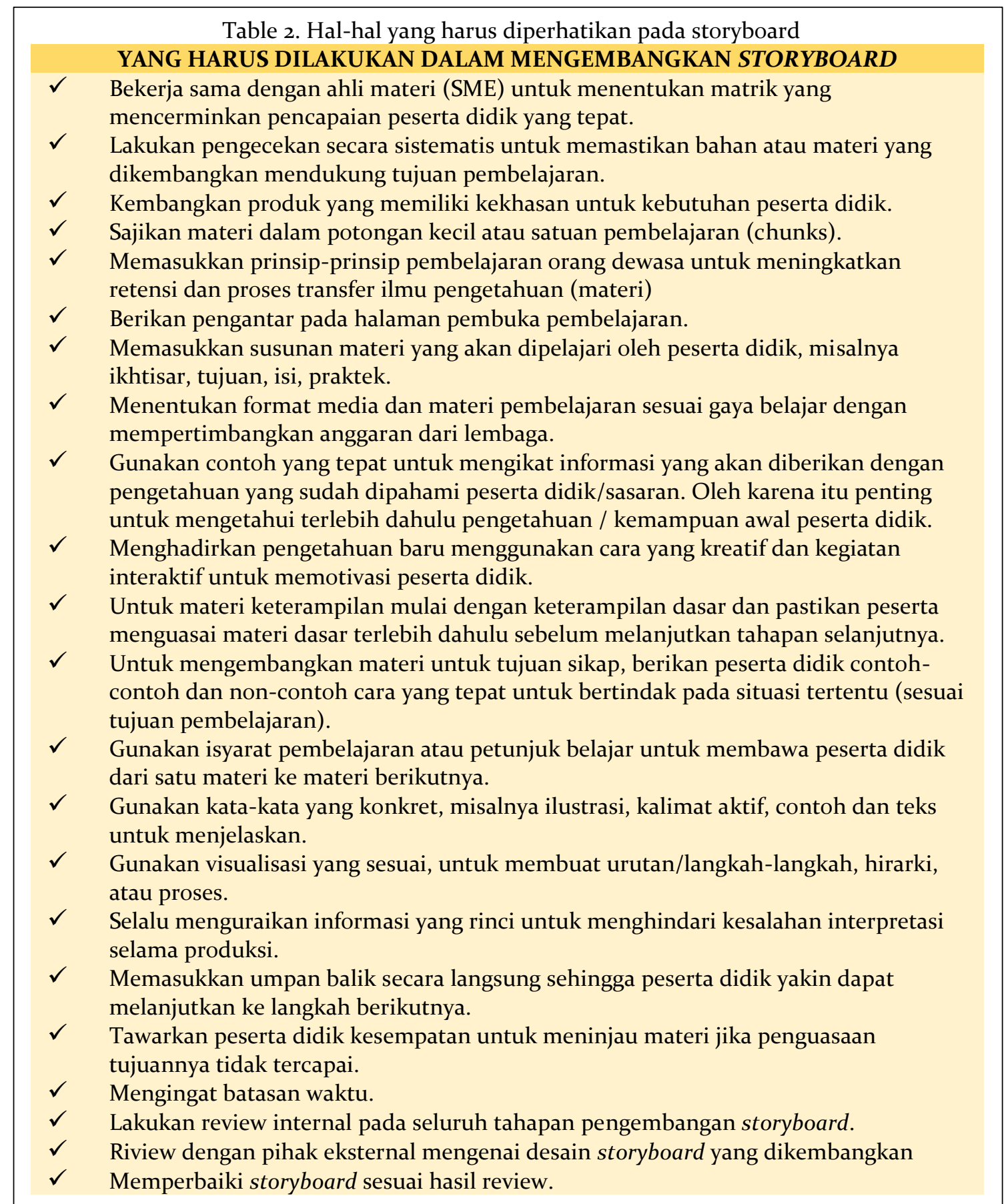

beradaptasi terhadap gaya yang bermacam. Mereka harus mampu untuk mengikuti desain yang telah dikeluarkan dan menghasilkan kerja konsisten, yang digambar pada model.

Namun demikian, Storyboard sering kali diabaikan dalam proses pengembangan media pembelajaran, selain dari itu, dalam mengembangan media pembelajaran, storyboard yang digunakan memiliki kekhususan dibandingkan dengan storyboard yang digunakan untuk mengembangkan media non pembelajaran.

Beberapa hal yang perlu diingat ketika memilih elemen multimedia dalam storyboard :

a. Media yang dipilih harus selalu mendukung tujuan pembelajaran

b. Media harus memiliki tujuan yang jelas tidak hanya menggunakan media agar memiliki kesan modern, namun perlu ada tujuan dalam memilih suatu jenis media. 
c.Pertimbangkan latar belakang
teknologi peserta didik.

Dean Hawkinson menyatakan Beberapa hal yang perlu diingat ketika memilih elemen multimedia dalam storyboard:

a. Pilihan media yang dipilih harus selalu mendukung tujuan pembelajaran

b. Media harus memiliki tujuan yang jelas tidak hanya menggunakan media agar memiliki kesan modern, namun perlu ada tujuan dalam memilih suatu jenis media.

c. Jauhkan keterbatasan teknologi yang dimiliki peserta didik dan pastikan komputer yang digunakan peserta didik dapat mendukung media yang dipilih dalam storyboard

d. Jika menggunakan video untuk pembelajaran e-Learning, maka gunakan video dengan durasi pendek antara 3-5 menit.
2. Hal ini dapat berfungsi sebagai instruksi untuk pengembang ketika tahap pembuatan.

Beragam media dalam proses produksinya membutuhkan storyboard sebagai blue-print dasarnya seperti, teknologi cetak (Ebook), teknologi audio-visual, teknologi berbasis komputer, multimedia. Beberapa jenis media menggunakan format linear dan nonlinear dengan memperhatikan beberapa komponen utama yang harus ada pada penyajiannya. Komponen tersebut dapat seluruhnya digunakan maupun hanya sebagiannya saja tergantung kebutuhan pengembangannya. Komponen tersebut sebagaimana terlihat pada ilustrasi (gambar.2) berikut ini:

Penyajian format linear dan non-linear tidak boleh sembarang, namun harus memperhatikan beberapa komponen utama yang harus ada didalamnya. Komponen tersebut dapat seluruhnya digunakan maupun hanya

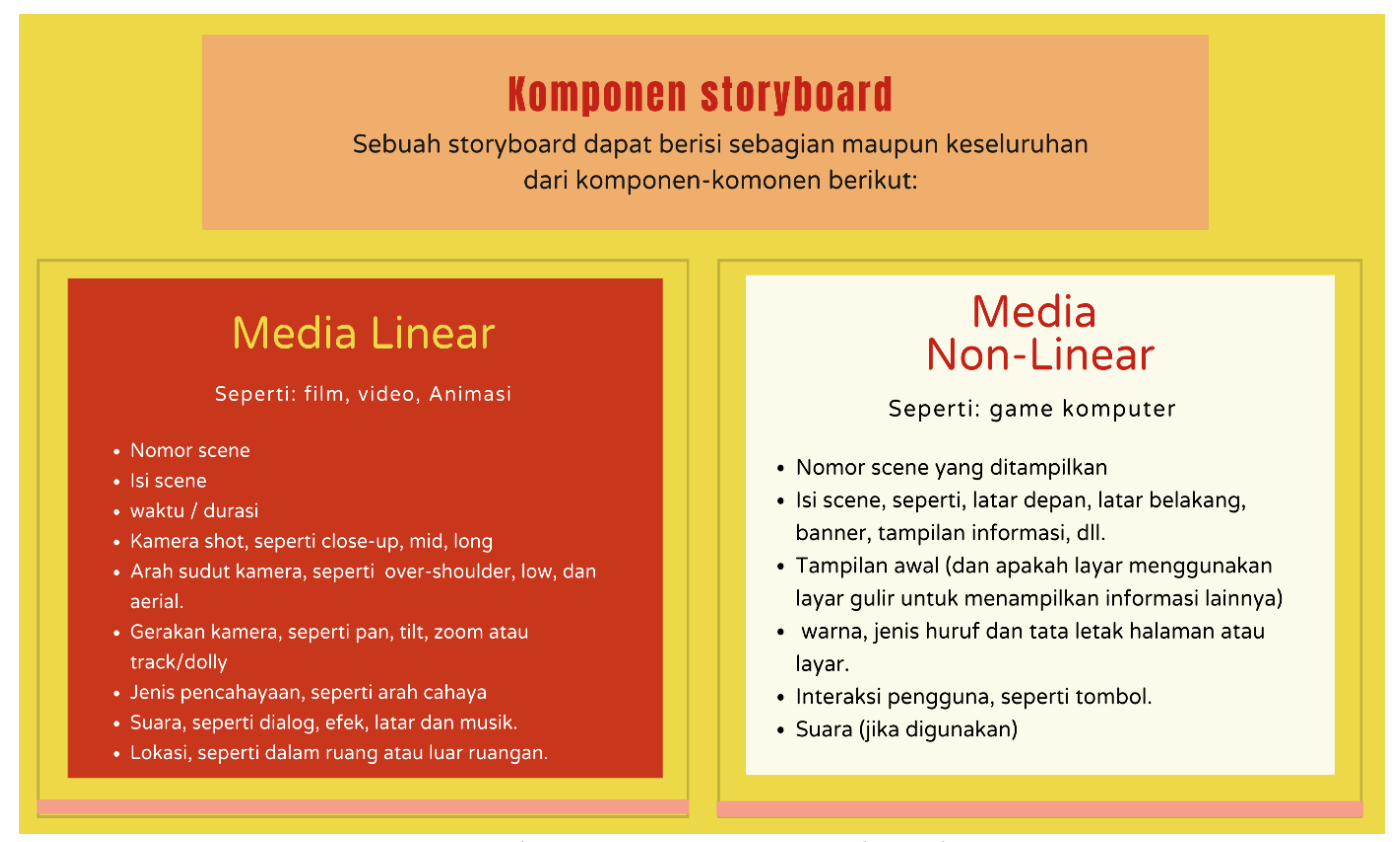

Gambar 3. Komponen storyboard

Desainer pembelajaran menggunakan storyboard untuk mengkomunikasikan isi pembelajaran dan pola interaksi kepada pengembang untuk menghasilkan media pembelajaran. Storyboard dalam produksi media pembelajaran dapat dilihat dari beberapa tujuan yang berbeda:

1. Dapat memudahkan subject matter experts (SMEs) untuk meninjau konten pada tahap pengembangan. sebagiannya saja tergantung kebutuhan pengembangannya. Komponen tersebut sebagaimana terlihat pada penjelasan oxford cambridge and RSA (gambar.3) berikut.

Hasil penelitian diperoleh setelah melaksanakan keseluruhan dari model pengembangan ADDIE, berikut adalah uraian tiap tahapan pengembangan. 


\section{A. Analisis (Analyze).}

Pada tahap ini dilakukan analisis kepada para pengembang media yang sudah memiliki pengalaman dalam mengembangan media pembelajaran secara komersil. Pada penelitian ini melibatkan 19 orang sebagai sumber data dengan memberikan berbagai sudut pandangnya yang digunakan sebagai acuan dalam melakukan desain dan pengembangan storyboard, diantaranya:

1. Kedudukan Storyboard dalam pengembangan media pembelajaran. Berdasarkan pengumpulan data, diperoleh kesimpulan bahwa posisi sebuah story board tidak dapat digantikan dalam sebuah pengembangan media pembelajaran, terutama jika pengembangan dilakukan oleh tim.

2. Kendala dalam menggunakan storyboard dalam pengembangan media pembelajaran. Adapun yang paling sering ditemui adalah banyak pihak yang ingin melewati tahapan penggunaan storyboard dan langsung melakukan pengembangan media pembelajaran. Hal ini dapat terjadi dikarenakan kurangnya pemahaman akan arti dan fungsi dari storyboard. Kendala lain yang sering kali ditemui adalah, pihak ahli materi atau Subject Matter Expert yang kurang menguasai disain pembelajaran, sehingga ketika storyboard telah dikembangkan, maka para ahli ini menginginkan "semua materi" dimasukan kepada storyboard dan media pembelajaran yang dikembangkan, tanpa memperhatikan tujuan pembelajaran yang sudah ditentukan.

3. Komponen yang harus ada dalam sebuah storyboard pengembangan media pembelajaran. Terdapat banyak sekali template dari storyboard yang ada saat ini, namun pada penelitian ini, pengembang menanyakan komponen apa saja dalam sebuah storyboard pengembangan media pembelajaran yang harus ada.

\section{B. Disain (Design).}

Tahap ini dikenal dengan istilah membuat rancangan (blue print), selain itu dalam tahap disain ini, hasil dari tahap analisis sepenuhnya digunakan sebagai acuan. Rancangan yang dikembangkan dalam antara lain adalah memperhatikan Komponen Storyboard dan Tips dalam menggunakan Storyboard.

Komponen storyboard diantaranya yaitu :

1. Judul dan nomor scene

2. Kolom visual

3. Kolom audio

4. Kolom interaktifitas

5. Data person in charge (PIC)

6. Tanggal release storyboard

7. Nomor versi storyboard

8. Kolom tandatangan PIC

Berdasarkan hal-hal ini, maka hasil atau produk dari penelitian pengembangan ini akan meliputi rangkaian storyboard yang terdiri atas:

1. Template Storyboard media Linear.

2. Template Storyboard media NonLinear.

\section{Pengembangan (Development).}

Merupakan proses mewujudkan blueprint alias desain tadi menjadi kenyataan. Artinya pada tahap ini segala sesuatu yang dibutuhkan atau yang terkait dikembangkan pada bentuk yang lebih konkrit.

Produk yang dikembangkan pada tahap ini mengacu pada hasil dari tahapan disain, yaitu akan mengembangkan Template Storyboard Media Linear dan Template Storyboard Media Non-Linear.

\section{Implementasi (Implementation).}

Setelah produk siap, maka kedua jenis produk yang telah dikembangkan diimplementasikan di Lembaga LOOKMEDIA Kedua produk yang sudah kembangkan selanjutnya diimplementasikan oleh para Desainer Pembelajaran di Lembaga ini sesuai dengan keperluan. terdiri dari orang-orang profesional dan terbaik di bidangnya. Terdapat seniman $2 \mathrm{D}$ dan $3 \mathrm{D}$, ilustrator, videografer dan fotografer, pengembang situs web, desainer instruksional, spesialis e-learning, pembuat konten, dan spesialis pemasaran digital.

Dengan spesifikasi tersebut, maka storyboard merupakan sebuah alat bantu wajib yang digunakan pada Lembaga ini. 


\section{E. Evaluasi (Evaluation).}

Pada tahapan ini, evaluasi yang dilakukan adalah evaluasi formatif, yaitu evaluasi yang dilakukan untuk memperbaiki kualitas produk yang telah dikembangkan. Pihak yang terlibat pada tahapan ini adalah seluruh desainer pembelajaran yang ada di LOOKMEDIA. Berdasarkan hasil analisis data pada tahap evaluasi didapatkan informasi sebagai acuan pengembangan melakukan perbaikan (revisi) terhadap produk ragam storyboard. Adapun hasil revisi pada (gambar.4) berikut.

Cover pada storyboard baik linear dan non linear setidaknya memuat komponen judul project, tujuan pembelajaran, format media/treatment, identitas klien, nama project manager, nama instructional designer, tanggal terbit storyboard, nomor versi storyboard, nama Subject mater expert dari sisi klien, dan nota validasi.
Komponen pertama yakni judul project berfungsi sebagai identitas utama storyboard yang menunjukkan apa yang akan dan sedang dikerjakan oleh tim pengembang, dapat berisi nama pelajaran, ama matakuliah ataupun nama mata diklat. Komponen ke-dua ialah tujuan pembelajaran, dimana komponen ini akan menggambarkan ruang lingkup project yang dikerjakan, seorang desainer instruksional yang mengembangkan storyboard akan sangat bergantung pada komponen ini karena tujuan pembelajaran menggambarkan ruang lingkup, kedalaman dan bobot materi yang dikembangkan. Ketiga, format media/treatment mengandung informasi mengenai apa jenis media yang dikembangkan sekaligus memberikan informasi tindaklanjut produksi yang akan dilaksanakan, apakah harus melakukan pengambilan gambar dengan syuting atau produksi akan sepenuhnya dengan Teknik animasi.

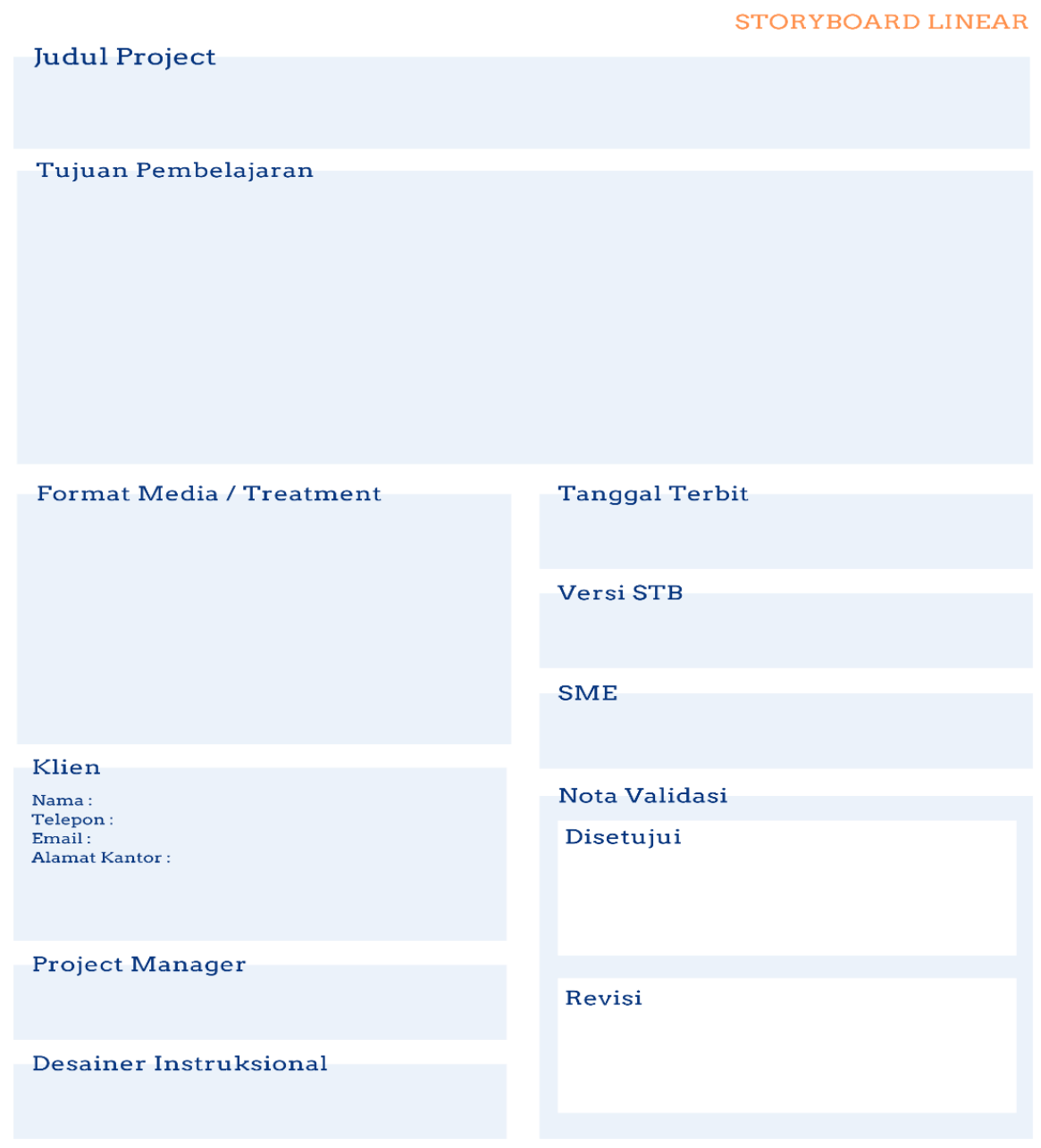

Gambar 4: Template Storyboard Linear - Cover 


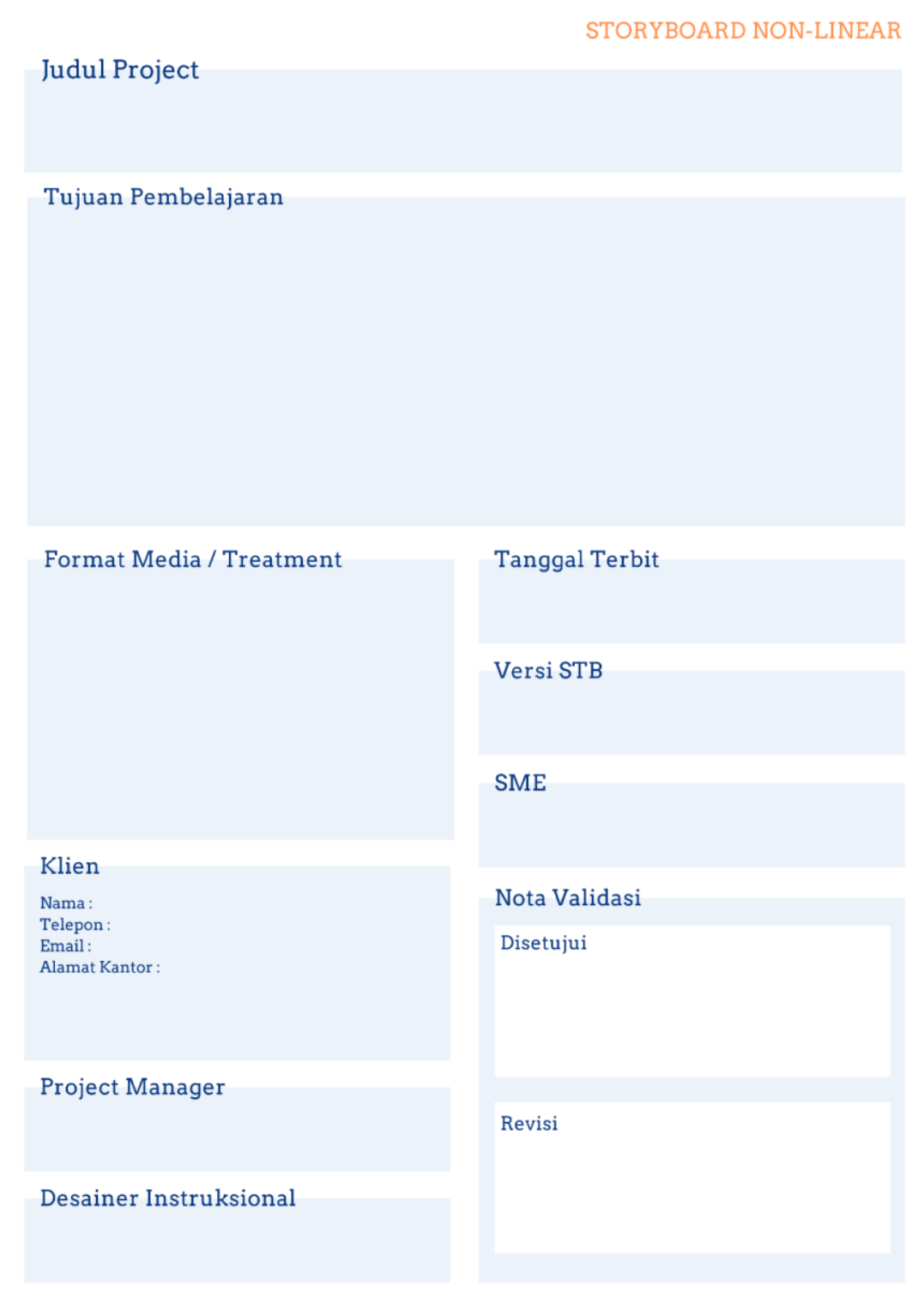

Gambar 5: Template Storyboard Non-Linear - Cover

Komponen ke-empat adalah identitas klien, penting sekali untuk mencantumkan siapa klien yang memberikan pekerjaan tersebut. Informasi seperti nama klien (baik individua atau perusahaan/lembaga), kontak telepon dan email yang bisa dihubungi, serta alamat kantor. Komponen ke-lima adalah nama project manager, hal ini penting untuk menjamin siapa yang berwenang mengelola seluruh SDM yang terlibat dalam produksi agar timeline pengembangan produk dapat berjalan baik. Selanjutnya komponen ke-enam adalah nama desainer instruksional, dialah yang akan mengembangkan storyboard dan berkomunikasi dengan SME (subject mater expert) dari sisi klien selama proses pengembangan storyboard berlangsung. Dibagian selanjutnya sebagai komponen ketujuh adalah tanggal terbit storyboard, yang menandakan kapan versi storyboard tersebut diterbitkan oleh desainer instruksional kepada SME dan tanggal juga akan menandakan sudah sejauh mana tahapan pengembangan produk secara keseluruhan pada timeline yang telah ditentukan sebelumnya. Komponen selanjtnya yang masih terkait dengan tanggal adalah 
komponen ke-delapan yaitu nomor versi storyboard, hal ini penting karena dalam sebuah proses pengembangan produk media pasti ada proses review kepada SME yang tidak jarang menuntut penyesuaian dalam storyboard sehingga memunculkan versi baru dari storyboard yang di review oleh SME tadi. Terkait dari sisi klien maka nama Subject mater expert penting untuk dicantumkan sebagai komponen ke-sembilan, SME adalah seseorang yang ditunjuk oleh klien sebagai rujukan dan dipandang memiliki kapasitas dalam melakukan validasi isi dari materi yang dikembangkan dalam media tersebut dan akan sering berhubungan langsung dengan desainer instruksional secara langsung.

Komponen selanjutnya ke-sepuluh adalah nota validasi, nota ini diisi oleh SME setelah yang bersangkutan melakukan review terhadap storyboard yang diterbitkan oleh desainer instruksional. Terdapat dua rekomendasi sebagai isi nota validasi tersebut yaitu "Disetujui" jika storyboard telah memenuhi harapan klien yang diwakili oleh SME, ataupun

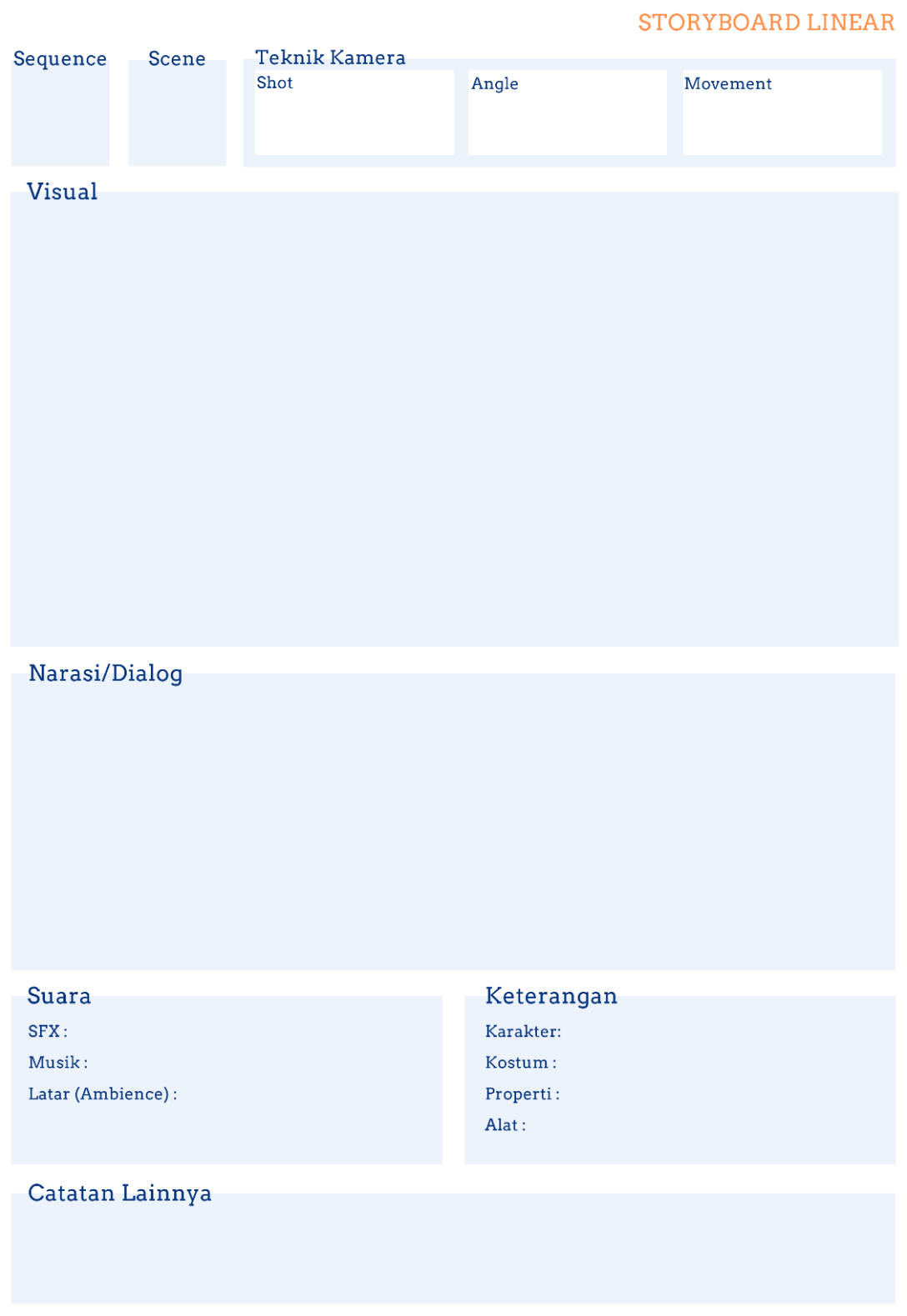

Gambar 6: Template Storyboard Linear - Scene 
"Revisi" jika SME merasa masih harus ada yang disesuaikan tentunya melalui diskusi produktif bersama desainer instruksional.

Storyboard linear dan non-linear selain format template pada cover juga dilengkapi format template "Scene". Scene pada storyboard berperan sebagai uraian esensi konten yang akan tersaji pada layar. Kedua template linear dan non-linear secara khusus memiliki komponen yang agak sedikit berbeda pada beberapa bagiannya. Template scene storyboard linear berisi komponen sequence, scene, teknik kamera, kolom visual, narasi/dialog, suara, keterangan dan catatan lainnya. Sedangkan template scene storyboard non-linear memiliki komponen nomor scene, treatment, kolom visual, narasi/dialog, suara, interaksi dan catatan.

Template scene storyboard linear komponen pertama adalah sequence (sekuen) yang merupakan kumpulan dari beberapa scene, sehingga dengan memberikan kode nomor pada sekuen akan memudahkan pengelolaan urutan linear dari media. Erat dengan sekuen, komponen ke-dua yaitu scene, penomorannya juga berfungsi sebagai koridor konten materi yang dikembangkan. Komponen ke-tiga yaitu teknik kamera, pada komponen ini terbagi menjadi tiga keterangan tambahan yakni shot, angle dan movement. Kamera shot seperti closeup/mid/long shot. Kamera angle seperti aerial sudut dari udara, low angle yang membuat objek menjadi membesar ataupun sudut kamera lainnya sesuai kebutuhan penyajian materi. Sedangkan kamera movement terkait dengan pergerakan kamera seperti pan yang membuat seolah kamera menoleh ke kanan atau kekiri, kamera tilt yang membuat kamera seolah mengubah ketinggian pandangannya, dan pergerakan yang menggunakan dolly misalnya.

Selanjutnya adalah komponen ke-empat yaitu visual, kolom visual memiliki ukuran yang sangat besar pada template karena disinilah bentuk visual yang ingin ditampilkan pada layar disusun. Didalamnya menggambarkan seluruh visual harus diwujudkan oleh tim produksi grafis, animator, dan editor. Komponen yang juga penting selanjutnya yaitu komponen kelima narasi/dialog, kolom juga hampir sama besar karena akan menampung teks narasi atau dialog yang bisa jadi cukup banyak dan terintegrasi bersama visualnya. Komponen keenam yaitu suara, suara memiliki tiga detil bagian lainnya yakni SFX atau efek suara dari objek-objek yang muncul di layar, musik yang akan memberikan nuansa tertentu pada penyajian, dan juga latar (ambience) yang dapat memunculkan karakteristik tertentu dari konteks materi yang disajikan, misal suara latar air sungai, suara latar lalu lintas kendaraan, dll.

Komponen ke-tujuh yaitu keterangan, disini ada beberapa hal yang dapat dituliskan untuk menambah detil kesiapan produksi seperti karakter apa yang akan muncul atau digunakan, kostum yang sesuai dengan konteks materi, dan juga properti serta alat bilamana secara teknis dibutuhkan Ketika melakukan teknis produksi. Pada komponen terakhir yaitu catatan lainnya, merupakan kolom bebas yang disediakan untuk mengakomodir ruang kolom lainnya bilamana dibutuhkan penjelasan maupun keterangan lainnya yang sekiranya dirasa perlu disampaikan oleh desainer instruksional kepada tim produksi selanjutnya. Sedangkan pada template scene storyboard nonlinear komponen pertama yaitu nomor scene, penomorannya berfungsi sebagai koridor berapa banyak konten materi yang akan dikembangkan. Komponen ke-dua yaitu treatment, disini dituliskan penjelasan apa saja treatment tipe media non-linear apa yang akan dikembangkan. Komponen ke-tiga yaitu kolom visual, kolom visual memiliki ukuran yang sangat besar pada template karena disinilah bentuk visual yang ingin ditampilkan pada layar disusun. Didalamnya menggambarkan seluruh visual harus diwujudkan oleh tim produksi grafis, animator, editor dan programer. Komponen yang juga penting selanjutnya yaitu 

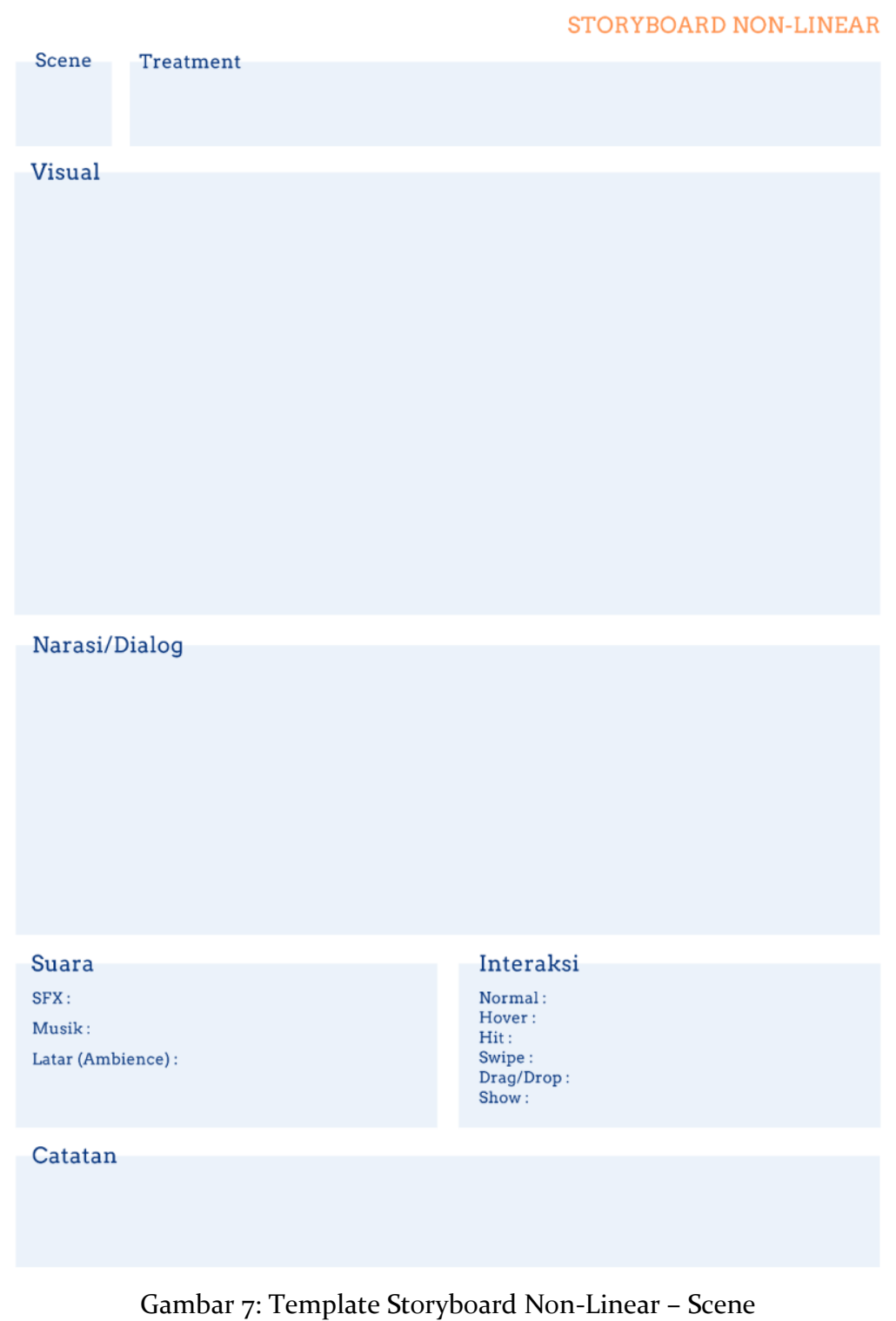

komponen ke-empat narasi/dialog, kolom juga hampir sama besar karena akan menampung teks narasi atau dialog yang bisa jadi cukup banyak dan terintegrasi bersama visualnya. Komponen ke-lima yaitu suara, suara memiliki tiga detil bagian lainnya yakni SFX atau efek suara dari objek-objek yang muncul di layar seperti efek tombol ketika di klik atau efek suara sebuah objek ketika muncul pada layar, pemilihan musik akan memberikan nuansa tertentu pada atmosfer ketika menggunakan medianya, dan juga latar (ambience) yang dapat memunculkan karakteristik tertentu dari konteks materi yang disajikan, misal suara latar pasar tradisional atau suara latar jangkrik yang menandakan malam yang tenang, dll.

Selanjutnya komponen ke-enam yaitu interaksi, komponen ini menjadi pembeda utama antara non-linear dengan linear. Keterangan tercantum adalah normal, hover, dan hit merupakan kode aksi untuk tombol sedangkan swipe, drag/drop dan show merupakan kode aksi untuk interaksi objek sesuai kebutuhan penyajian materi. Sedangkan komponen terakhir yaitu catatan yang berfungsi sebagai kolom bebas yang disediakan untuk mengakomodir bilamana dibutuhkan penjelasan maupun keterangan lainnya yang sekiranya dirasa perlu disampaikan oleh desainer instruksional kepada tim produksi selanjutnya. 


\section{SIMPULAN}

Hasil dari penelitian pengembangan ini adalah produk berupa storyboard untuk produksi media digital. Model pengembangan ini menggunakan framework ADDIE.

Penelitian ini menunjukkan bahwa sebuah storyboard hendaknya memuat beberapa komponen utama yang terbagi pada dua buah format yakni storyboard linear dan storyboard non-linear, Adapun kedua template tersebut dibagi lagi menjadi dua yakni format cover dan format scene.

Cover pada storyboard baik linear dan non linear setidaknya memuat komponen judul project, tujuan pembelajaran, format media/treatment, identitas klien, nama project manager, nama instructional designer, tanggal terbit storyboard, nomor versi storyboard, nama Subject mater expert dari sisi klien, dan nota validasi.

Storyboard linear dan non-linear selain format template pada cover juga dilengkapi format template "Scene". Scene pada storyboard berperan sebagai uraian esensi konten yang akan tersaji pada layar. Kedua template linear dan non-linear secara khusus memiliki komponen yang agak sedikit berbeda pada beberapa bagiannya. Template scene storyboard linear berisi komponen sequence, scene, teknik kamera, kolom visual, narasi/dialog, suara, keterangan dan catatan lainnya. Sedangkan template scene storyboard non-linear memiliki komponen nomor scene, treatment, kolom visual, narasi/dialog, suara, interaksi dan catatan.

Storyboard Linear dan Non-linear ini sangat direkomendasikan untuk digunakan oleh pengembang media pembelajaran pemula maupun professional.

\section{UCAPAN TERIMA KASIH}

Ucapan terima kasih penulis tujukan kepada pihak sponsor dalam penelitian ini yakni Universitas Negeri Jakarta dengan harapan bahwa Ragam Storyboard dapat berkontribusi positif dalam berbagai pengembangan media pembelajaran dimasa yang akan datang.

\section{DAFTAR PUSTAKA}

Azhar Arsyad. (2008). Media Pembelajaran. Jakarta: PT Radja Grafindo Persada.

Bambang Warsita. Perkembangan Definisi Dan Kawasan Teknologi Pembelajaran Serta Perannya Dalam Pemecahan Masalah Pembelajaran. Fungsional Pengembang Teknologi Pembelajaran PUSTEKKOM.

Euis Ismayati, Dosen Jurusan Teknik Elektro Fakultas Teknik UNESA. Pengembangan Media Pembelajaran Menggunakan Model CAI Sebagai Upaya Memperbaiki Kualitas Pembelajaran Pada Mata Kuliah Fisika Optik. INVOTEC, Volume VII, No. 1, Februari 2011: $13-28$

http://digilib.unila.ac.id/1406/9/BAB\%2oIII.pdf http://tekaje.mahadhika.or.id/20172018/STORYBOARD/211554570-ModulStoryboard.pdf

I Wayan Adi Ambhara Sanuaka1, Ketut Udy Ariawan2, I Wayan Sutayaz. Pengembangan Media Pembelajaran Electronic Book (E-Book) Interaktif Multimedia Dalam Mata Pelajaran Teknik Animasi 3d Dan Teknik Animasi 2d Di Jurusan Multimedia Smk Negeri 3 Singaraja. Jurnal Pendidikan Teknik Elektro Undiksha Vol. 8 No. 1, April 2017 ISSN: 2599-1531

Kandriasari, A., Situmorang, R., Muslim, S., \& Lagun Siang, J. (2019). HOW TO DEVELOP A BREAD PROCESSING VIDEO STORYBOARD. Asia Proceedings of Social Sciences, 5(2), 137-141. https://doi.org/10.31580/apss.v5i2.1132

Kustandi, Cecep,. Dan Sutjipto, Bambang. (2013). Media Pembelajaran: Manual dan Digital. Bogor. Ghalia Indonesia.

Nur Hadi Waryanto, Jurusan Pendidikan Matematika FMIPA UNY. Storyboard Dalam Media Pembelajaran Interaktif

Smaldino Sharon E, Debora L.Lowther, James D Russel. (2008). Instructional Technology and Media for Learning. New Jersey: Pearson Prentice Hall.

The OCR Guide to Storyboards, https://pdf.ocr.org.uk/Images/168849 -the-ocr-guide-to-storyboards.pdf

Walter Dick, L. C. dan J. O. C. (2009) The Systematic Design of Instruction 7ed. Boston: pearson. 